\title{
Hubungan Analisis Transaksional Dengan Proses Pembelajaran Dalam Mata Pelajaran IPS Ekonomi Siswa Kelas VIII SMP Negeri 3 Ulaweng Kecamatan Ulaweng Kabupaten Bone
}

\author{
Haeril \\ Universitas Muhammadiyah Bone \\ Email: haerilkacong@gmail.com
}

\begin{abstract}
Abstrak. penelitian ini bertujuan untuk mengetahui hubungan analisis transaksional dengan proses pembelajaran dalam mata pelajaran ips ekonomi siswa kelas VIII SMP Negeri 3 Ulaweng Kecamatan Ulaweng Kabupaten Bone serta gambaran hubungan analisis transaksional dengan proses pembelajaran tersebut. Jenis penelitian ini adalah penelitian Kuantitatif dalam bentuk eksperimen yaitu penelitian yang bersifat korelasional untuk mengetahui pengaruh anatara variabel $\mathrm{X}$ dan variabel $\mathrm{Y}$. Penelitian ini merupakan penelitian yang bersifat Kuantitatif yaitu hasil penelitian diperoleh dalam bentuk angka. Hubungan analisis transaksional adalah merupakan suatu cara untuk menganalisis bagaimana hubungan dengan analisis transaksional dalam proses pembelajaran. Adanya hubungan yang signifikan dimana $r$ hitung lebih besar daripada $r$ tabel product moment yaitu $r$ hitung $=0,694$ untuk $\mathrm{r}$ tabel 5 persen $=0,297$ dan 1 persen $=0,384$ dimana $\mathrm{N}=44$, maka Hipotesis alternatif $(\mathrm{H} 1)$. Diterima.
\end{abstract}

\section{PENDAHULUAN}

Pendidikan adalah usaha sadar dan terencana untuk mewujudkan suasana belajar dan proses pembelajaran agar peserta didik secara aktif mengembangkan potensi diri untuk memiliki kekuatan spritual keagamaan, pengendalian diri, kepribadian, kecerdasan, akhlak mulia, serta keterampilan yang diperlukan dirinya, masyarakat, bangsa dan negara.Berdasarkan Undang-Undang RI No. 20 Tahun 2003 tentang Sistem Pendidikan Nasional dinyatakan bahwa :

"Pendidikan nasional bertujuan mengembangkan potensi peserta didik agar menjadi manusia yang beriman dan bertakwa kepada Tuhan Yang Maha Esa, berakhlak mulia, sehat, berilmu, cakap, kreatif, mandiri, dan menjadi warga negara yang demokratis serta bertanggung jawab dalam rangka mencerdaskan kehidupan bangsa".

Sehubungan dengan itu, dalam Undangundang tersebut dinyatakan bahwa Pendidikan Nasional bertujuan meningkatkan kualitas manusia Indonesia, yaitu manusia yang beriman dan bertaqwa kepada Tuhan Yang Maha Esa, berbudi pekerti luhur, berkepribadian mandiri, Jurnal Pendidikan Mandala maju, tangguh, cerdas, kreatif, terampil dan disiplin. Pendidikan adalah usaha sadar dan terencana untuk mewujudkan suasana belajar dan proses pembelajaran agar peserta didik secara aktif mengembangkan potensi diri untuk memiliki kekuatan spritual keagamaan, pengendalian diri, kepribadian, kecerdasan, akhlak mulia, serta keterampilan yang diperlukan dirinya, masyarakat, bangsa dan negara. Amier (dalam Indra Kusuma (2001: 35) Pendidikan nasional adalah pendidikan yang berdasarkan Pancasila dan UndangUndang Dasar Republik Indonesia tahun 1945, yang berakar pada nilai-nilai agama, kebudayaan nasional dan tanggapan terhadap tuntutan perubahan zaman.

Kemajuan pendidikan saat ini telah kita maklumi bersama bahwa innovasi dalam dunia pendidikan memerlukan waktu yang tidak pendek, di samping diperlukan pula petugaspetugas yang cukup tangguh. Namun demikian kita harus masih menyadari bahwa dunia pendidikan khususnya dunia pengajaran di negara kita masih banyak terpengaruh oleh sistem lama yang telah bercokol sejak jaman penjajahan. Hal ini sangat sulit untuk dapat 
dihilangkan begitu saja. Oleh karena itu, dalam kita mempersiapkan para guru/pendidik pada umumnya perlu memperhatikan hal tersebut di atas.

Sifat otoriter dan sifat-sifat tradisional dan konservatif masih begitu tampak menonjol pada guru kita. Mereka melaksanakan tugas mendidik dan mengajar bahkan lebih tepat bila diistilahkan mengajar saja, secara tradisional dan konservatif itu. tradisional dalam arti melaksanakan tugas dengan mendasarkan diri pada tradisi atau apa yang telah dilaksanakan oleh para guru/pendidik dahulu tanpa ada usaha untuk memperbaiki dengan daya kreasi yang telah dianjurkan. Iskandar Wiryo ( dalam Mandalica :2003: 34)

Konservatif dalam arti bertindak secara kolot menurut cara-cara lama yang kurang atau tidak sesuai lagi dengan perubahan dan kemajuan jaman. Jadi sifat-sifat tradisional dan konservatif dalam pelaksanaan pada prinsipnya tidak berubah.

Mengajar secara lama berarti guru berpesan sebagai seorang autokrat. Sehingga dia bertindak main kuasa terhadap siswanya, siswa dalam hal ini dianggap sebagai botol kosong yang harus diisi dengan berbagai pengetahuan oleh para guru sesuai dengan kehendak guru dan kurikulum yang ada. Dengan demikian siswa akan menjadi bersifat pasif dan teleseptif saja. pengajaran semacam ini akan berakibat timbulnya dan merajalelanya intelektualisme dan vervalisme dalam dunia pendidikan.

Dengan analisis transaksional ini diharapkan guru sebagai pendidik pada umumnya dapat melaksanakan tugas mendidik dan mengajar (melaksanakan proses pembelajaran) secara wajar terhadap mata pelajaran ekonomi khususnya dan mata pelajaran yang lain pada umumnya. Sehingga siswa atau anak didik tidak hanya difungsikan sebagai objek semata, melainkan mereka juga berfungsi sebagai subjek pula. Dengan demikian diharapkan hasil proses pembelajaran terhadap mata pelajaran ekonomi dan pelajaran yang lainnya dapat tercapai secara optimal.

\section{Pengertian Analisis}

Dalam penelitian harus didukung oleh teori-teori yang relevan dan dapat digunakan sebagai landasan dalam suatu kegiatan penelitian. Sehubungan dengan hal tersebut, maka berikut ini dikemukakan beberapa teoriteori ataupun pengertian-pengertian yang menyangkut dengan judul penulis dalam penelitian ini.

Menurut Nurkancana (2002 : 29) Analisis adalah suatu uraian, dalam hal ini dimaksudkan suatu penggarapan yang bersifat menguraikan dalam arti suatu penelaahan atau penelitian secara mendalam untuk mencapai tujuan tertentu.

Campas L,Cormick P.M.Sc (2000 : 54) Memang istilah "mendalami" disini sebenarnya kurang begitu tepat, tetapi untuk mempermudah pengertian-pengertian kita saya rasa penggunaan istilah tersebut cukup memadai.

\section{Pengertian Transaksional}

Istilah ini berasal dari istilah transaksi, dalam bahasa Inggris kita dapati istilah "transaction" yang berarti pelaksanaan, perjanjian. Dalam judul itu dimaksud sebagai kegiatan dari dua pihak atau lebih dalam rangka melaksanakan tindakan tertentu atau untuk mencapai tujuan tertentu. Sedang istilah transaksional merupakan istilah pembendaan (pembentukan kata benda).

\section{Proses Pembelajaran}

Istilah ini merupakan rangkaian istilah yang telah cukup populer dalam dunia pendidikan dan pengajaran, yakni hubungan antara pihak pengajar (guru) dan pihak yang diajar (siswa) sehingga terjadi suasana dimana pihak siswa aktif belajar dan pihak guru aktif mengajar/memberikan pendidikan. Dengan demikian tidak terjadi proses pembelajaran tradisional dimana pihak guru/pengajar dominan dalam arti guru aktif, siswa bersifat pasif atau lebih tepat bersifat menerima (receptive) saja. Pengajaran modern kedua belah pihak bersifat aktif. 


\section{Manfaat Analisis Transaksional dalam Proses Pembelajaran}

Proses pembelajaran merupakan suatu kontak sosial antara guru (pengajar) dengan siswa (si terdidik) dalam rangka mencapai tujuan tertentu, yakni tujuan pendidikan dan pengajaran. Dalam proses ini dikehendaki bukan pihak guru yang aktif memberi pelajaran sedang siswa secara pasif menerima pelajaran, melainkan kedua belah pihak harus aktif.

\section{Aplikasi dan Penerapan dalam Proses Pembelajaran}

Setelah serba sedikit dikemukakan tentang pengertian, manfaat serta kegunaankegunaan analisis transaksional, maka tiba saatnya untuk dikategorikan tentang pentingnya dalam dunia pendidikan dan pengajaran, khususnya dalam proses pembelajaran. Proses pembelajaran merupakan suatu kontak sosial antara guru (pengajar) dengan siswa dalam rangka mencapai tujuan tertentu. Disini dimaksudkan bukan hanya pihak guru yang aktif, melainkan justru para siswa yang harus lebih aktif.

\section{Hakikat Pembelajaran IPS Ekonomi di SMP}

Setiap bidang studi memiliki tujuan masing-masing yang sangat ditentukan oleh karakteristik dari masing-masing bidang studi tersebut. Ekonomi merupakan ilmu tentang perilaku dan tindakan manusia untuk memenuhi kebutuhan hidupnya yang bervariasi, dan berkembang dengan sumber daya yang ada melalui pilihan-pilihan kegiatan produksi, konsumsi, dan atau distribusi. Luasnya ilmu ekonomi dan terbatasnya waktu yang tersedia membuat standar kompetensi dan kompetensi dasar pada pembelajaran ekonomi (di SMP/MTs. skhususnya) dibatasi dan difokuskan kepada fenomena empirik ekonomi yang ada disekitar peserta didik sehingga peserta didik dapat merekam peristiwa ekonomi yang terjadi disekitar lingkungannya dan mengambil manfaat untuk kehidupannya yang lebih baik.

\section{METODE PENELITIAN Jenis Penelitian}

Jenis penelitian ini adalah penelitian Kuantitatif dalam bentuk eksperimen yaitu penelitian yang bersifat korelasional untuk mengetahui pengaruh anatara variabel $X$ dan variabel Y. Penelitian ini merupakan penelitian yang bersifat Kuantitatif yaitu hasil penelitian diperoleh dalam bentuk angka. Berdasarkan (Sugiyono, 2009 : 8 ) mengemukakan bahwa penelitian kuantitatif adalah penelitian yang menyajikan datanya berupa angka-angka dan menggunakan analisa statistik yang bertujuan untuk menunjukkan adanya pengaruh antara variabel dan, menguji teori dan mencari generalisasi yang mempunyai nilai prediksi dalam pengolahan data.

\section{Lokasi Penelitian}

Kegiatan penelitian ini dilakukan di SMP Negeri 3 Ulaweng yang tepatnya di Desa Cinnong Kecamatan Ulaweng Kabupaten Bone. Bone tahun pelajaran 2020/2021

\section{Waktu Penelitian}

Waktu penelitian selama 2 bulan yaitu mulai bulan Maret sampai dengan Mei 2020.

\section{Definisi Operasional Variabel}

Untuk memperjelas penelitian ini, maka perlu adanya pembatasan istilah sesuai dengan judul penelitian. Bertitik tolak dari judul skripsi ini yaitu Hubungan analisis transaksional dalam proses pembelajaran dalam mata pelajaran IPS Ekonomi siswa kelas VIII SMP Negeri 3 Ulaweng Kecamatan, Ulaweng Kabupaten Bone yaitu:

Analisis adalah suatu uraian dalam hal ini dimaksudkan suatu penggarapan yang bersifat menguraikan dalam suatu penelaahan atau penelitian secara mendalam untuk mencapai tujuan.

Proses pembelajaran adalah untuk mengetahui seberapa jauh keberhasilan menganalisis siswa dalam proses pembelajaran, maka dilaksanakan tes terhadap siswa dengan kriteria keberhasilan dalam mengerjakan soal-soal tes didasarkan pada standar penilaian. 


\section{Variabel Penelitian}

Variabel Penelitian sebelum diuraikan mengenai variabel yang diteliti dalam penelitian ini terlebih dahulu diuraikan pengertian variabel dalam suatu penelitian. Variabel tidak pernah lepas dari suatu penelitian dan boleh dikatakan bahwa variabel merupakan syarat mutlak yang harus ada dalam suatu penelitian. Hadi (dalam Arikunto, 2000 : 89) Dengan memperhatikan uraian di atas, maka dapatlah ditemukan variabel suatu penelitian yang sedang atau direncanakan. Sehubungan dengan hal itu pula, maka jelas variabel dalam suatu penelitian perlu dibatasi, agar data dan informasi yang dikumpulkan dapat mengarah pada tujuannya. Variabel dalam penelitian Analisis transaksional dalam proses pembelajaran sebagai variabel bebas (X),Hasil belajar IPS Ekonomi sebagai variabel terikat $(\mathrm{Y})$.

\section{Desain Penelitian}

Desain penelitian merupakan semua proses yang diperlukan dalam perencanaan penelitian. Adapun desain/rancangan penelitian terlihat pada tabel berikut:

Desain eksperimen yang berupa kelompok eksperimen yaitu:

Tabel 1. Desain penelitian

\begin{tabular}{llll}
\hline \multicolumn{1}{c}{ Kelas } & $\begin{array}{c}\text { Evaluasi } \\
\text { Awal } \\
\text { (Pretest) }\end{array}$ & $\begin{array}{c}\text { Perlakuan } \\
\text { (treatment) }\end{array}$ & $\begin{array}{c}\text { Evaluasi } \\
\text { Akhir } \\
\text { (Posttest) }\end{array}$ \\
\hline Eksprimen & $\sqrt{ }$ & $\sqrt{ }$ & $\sqrt{ }$ \\
Kontrol & $\sqrt{ }$ & - & $\sqrt{ }$ \\
\hline
\end{tabular}

\section{Instrumen Penelitian}

Instrumen yang digunakan dalam penelitian ini adalah :

\section{Angket}

Angket atau Qusioner adalah cara penilaian yang dirancang dan dilaksanakan kepada peserta didik pada waktu dan tempat tertentu serta dalam kondisi yang memenuhi syarat-syarat tertentu yang jelas (Anonim, 2009:38).

Peneliti mengumpulkan data dari angket siswa selama proses pembelajaran berlangsung di kelas VIII SMP Negeri 3 Ulaweng . angket untuk mengukur tingkat keberhasilan selama melakukan penelitian dengan menggunakan analisis transaksional

\section{Dekumentasi}

Dekumentasi atau arsip merupakan salah satu teknik pengumpulan data/fakta yang cukup efektif untuk mempelajari suatu sistem pengambilan data. Dekumentasi adalah laporan pendidikan guru atau nilai rapor siswa setelah terakhir evaluasi langsung . (Anonim, 2009: 45).

\section{Teknik Pengumpulan Data}

1. Teknis tes, yaitu merupakan sejumlah pertanyaan-pertanyaan ataupun latihan-

latihan lain yang digunakan untuk mengetahui keterampilan, pengetahuan,

bakat, minat, intelegensi, ataupun kemampuan individuatau kelompok orang.

2. Dokumentasi, yaitu penelitian yang dilakukan dengan jalan mengumpulkan dokumen-dokumen sekolah yang berhubungan dengan penelitian ini yaitu nilai prestasi belajar tahun pelajaran 2017/2018 pada semester Genap.

3. Quisioner atau angket, yaitu merupakan serentetan pertanyaan-pertanyaan untuk mengetahui keadaan seseorang atau hal-hal yang lain.

\section{Teknik Analisis Data}

Teknik analisis data adalah hasil penelitian berupa data mentah yang diperoleh dan dikumpulkan adalah dikaji dan diolah serta dianalisis dengan menggunakan teknik statistik deskriptif yaitu dengan menentukan :

a. Tabel frekuensi.

b. Proporsi.

c. Persentase.

d. Analisis validitas dan analisis statistik product moment.

Rumus Korelasi Pearson Product Moment (PPM)

$$
r_{\text {hitung }} \frac{n \cdot \sum X Y-\left(\sum X\right)\left(\sum Y\right)}{\sqrt{\left.\left\{n \cdot \sum X^{2}-\left(\sum X\right)^{2}\right\} n \cdot \sum Y^{2}-\left(\sum Y\right)^{2}\right\}}}
$$

(Bukhari Alma : $2010: 87$ )

Dimana : 


$$
\begin{array}{ll}
\mathrm{r}_{\text {hitung }} & =\text { Koefisien korelasi } \\
\mathrm{X} & =\text { Variabel Bebas } \\
\mathrm{Y} & =\text { Variabel Terikat } \\
\mathrm{n} & =\text { Jumlah responden } \\
\mathrm{r}_{\mathrm{xy}} & =\text { Koefisien korelasi }
\end{array}
$$

antara variabel $\mathrm{x}$ dan variabel, dua variabel yang dikorelasikan.

$$
\sum \mathrm{XY} \quad=\text { Jumlah perkalian }
$$

$\mathrm{x}$ dengan $\mathrm{y}$

$$
\begin{aligned}
& \mathrm{X}^{2}=\text { Kuadrat dari } \mathrm{x} \\
& \mathrm{Y}^{2}=\text { Kuadrat dari } \mathrm{y}
\end{aligned}
$$

Korelasi PPM dilambangkan (r) dengan ketentuan nilai $r$ tidak lebih dari harga $(-1<\mathrm{r}$ $\leq+1$ ). Apabila nilai $r=-1$ artinya korelasinya negatif sempurna; $r=0$ artinya tidak ada korelasi; dan $r=1$ berarti korelasinya sangat kuat.

\section{HASIL PENELITIAN}

Pada bagian ini dibahas secara rinci hasil penelitian sesuai data yang diperoleh di lapangan/sekolah terhadap variabel penelitian. Hasil penelitian ini terbagi atas dua bagian yaitu hasil atau data yang berbentuk bilanganbilangan yang disebut dengan data kuantitatif dan data/hasil yang berbentuk kategori-kategori atau disebut data kualitatif. Hasil kuantitatif adalah gambaran tingkat analisa siswa terhadap materi pelajaran Ekonomi siswa kelas VIII SMP Negeri 3 Ulaweng Kecamatan Ulaweng Kabupaten Bone 2020/2021 yang dinyatakan dalam bentuk angka-angka atau persentase. Sedangkan hasil kualitatif adalah untuk mengetahui tingkat keadaan analisa siswa terhadap materi pelajaran IPS Ekonomi siswa kelas VIII SMP Negeri 3 Ulaweng Kecamatan Ulaweng Kabupaten Bone yang dinyatakan dalam bentuk penilaian seperti : sangat tinggi, tinggi, cukup, rendah, buruk dan sebagainya. Untuk teknik tes soal ekonomi apabila dijawab benar mendapat skor 4 .

Berdasarkan tentang skor 0 - 100 hasil analisis data sampel menunjukkan bahwa skor terendah yang dicapai siswa adalah 50 sedangkan yang tertinggi adalah 93 .
Untuk mempermudah dan memperlancar pengolahan data yang telah terkumpul pada tabel 4.1 di atas, maka dapat dideskripsikan berdasarkan skor hasil tes menganalisis materi/soal pelajaran ekonomi, sebagaimana dapat dilihat pada tabel distribusi frekuensi skor nilai siswa di bawah ini :

a. Distribusi Frekuensi

Tabel 2. Nilai Tes IPS Ekonomi untuk 44 siswa kelas VIII SMP Negeri 3 Ulaweng Kecamatan Ulaweng Kabupaten Bone

\begin{tabular}{|c|lllllllllll|}
\hline No. & \multicolumn{10}{|c|}{ Total nilai untuk 44 siswa } \\
\hline 1. & 55 & 65 & 75 & 70 & 67 & 68 & 70 & 85 & 70 & 70 & 68 \\
2. & 84 & 75 & 80 & 78 & 55 & 76 & 82 & 64 & 70 & 75 & 85 \\
3. & 89 & 50 & 90 & 78 & 80 & 66 & 76 & 68 & 71 & 81 & 55 \\
4. & 79 & 89 & 93 & 88 & 81 & 67 & 88 & 63 & 81 & 76 & 59 \\
\hline
\end{tabular}

Sebelum menentukan interval kelas, tabulasi, frekuensi absolut dan frekuensi relatif, maka terlebih dahulu kita mengetahui langkahlangkah di bawah ini :

a. Menentukan rentang

Rentang adalah data terbesar dan data terkecil.

Data terbesar yaitu 93

Data terkecil yaitu 50

Rumus rentang adalah data terbesar dikurangi data terkecil yaitu :

$93-50=43$

b. Menentukan banyaknya interval

Rumus $=1+(3,3) \log \mathrm{n}$

$1+(3,3) \log 44$ (44 adalah

banyaknya data)

$1+(3,3)=(1,518)$

$1+5,009=6,009$

Jadi banyak kelas interval adalah 6 (angka enam merupakan hasil pembulatan).

c. Menentukan panjang kelas interval

Rumus $=\frac{\text { Rentang }}{\text { Banyaknya kelas interval }}-\frac{43}{6}=7,16$

Jadi panjang interval kelas adalah 7 (pembulatan) Untuk lebih jelasnya perhatikan tabel distribusi frekuensi berikut ini : 
Tabel 3. Distribusi Frekuensi siswa kelas VIII SMP Negeri 3 Ulaweng Kecamatan Ulaweng Kabupaten Bone

\begin{tabular}{|c|c|c|c|c|}
\hline No. & Interval Kelas & Tabulasi & Frekuensi absolut & Frekuensi Relatif \\
\hline 1. & $50-56$ & IIII & 4 & 9,09 \\
2. & $57-63$ & II & 2 & 4,54 \\
3. & $64-70$ & IIII IIIII III & 13 & 29,55 \\
4. & $71-77$ & IIIII II & 7 & 15,91 \\
5. & $78-84$ & IIIII IIII & 10 & 22,73 \\
6. & $85-91$ & IIIII II & 7 & 15,91 \\
7. & $92-98$ & I & 1 & 2,27 \\
\hline & Jumlah & 44 & 44 & 100,00 \\
\hline
\end{tabular}

Analisis Validitas

Untuk lebih memperjelas permasalahan tersebut, maka di bawah ini akan dibahas cara menghitung atau mengetahui tingkat validitas nilai tes yang diberikan terhadap kelas VIII A, VIII B, dan VIII C.

Perlu diketahui bahwa menurut Searvia B. Anderson dan kawan-kawan dalam bukunya "Encyclopedia of Educational Evaluation mengemukakan bahwa sebuah tes dikatakan valid apabila tersebut mengukur apa yang hendak diukur. Dalam bahasa Indonesia "Valid" disebut dengan istilah "Sahih".

Sekali lagi bahwa sebuah tes dikatakan memiliki validitas jika Hasilnya sesuai dengan kriterium, dalam arti memiliki kesejajaran atanra hasil tes tersebut dengan kriterium. Teknik yang digunakan untuk mengetahui kesejajaran adalah teknik korelasi product moment yang dikemukakan oleh (Pearson, 2001 : 116) yaitu rumus korelasi product moment dengan simpangan sebagai berikut :

$$
r_{\text {hitung }} \frac{n \cdot \sum X Y-\left(\sum X\right)\left(\sum Y\right)}{\sqrt{\left\{n \cdot \sum X^{2}-\left(\sum X\right)^{2}\right\}\left\{n \cdot \sum Y^{2}-\left(\sum Y\right)^{2}\right\}}}
$$

Dimana :

$$
\begin{aligned}
\mathrm{r}_{\mathrm{xy}} & =\text { Koefisien korelasi antara variabel } \\
& \mathrm{x} \text { dan variabel, dua variabel yang } \\
& \text { dikorelasikan. }
\end{aligned}
$$

Untuk lebih jelasnya kita akan menghitung validitas tes prestasi belajar ekonomi sebagai kriterium diambil rata-rata nilai ulangan harian yang terletak dalam daftar nilai. Nilai tes yang akan dicari validitasnya diberi kode $\mathrm{x}$ dan rata-rata nilai harian diberi kode y, kemudian kita buatkan tabelnya untuk melihat tingkat perbedaannya dan menghitung validitas tes prestasi belajar ekonomi antara kelas VIII A, VIII B, dan VIII C. kelas VIII SMP Negeri 3 Ulaweng Kecamatan Ulaweng Kabupaten Bone dapat dilihat pada lampiran 3

Tabel 4. Persiapan Mencari Validitas Tes Prestasi IPS Ekonomi untuk Kelas VII A dengan Rumus Koefisien Korelasi Product Moment dengan statistik Simpangan Siswa kelas VIII SMP Negeri 3 Ulaweng Kecamatan Ulaweng Kabupaten Bone

\begin{tabular}{ccccccccc}
\hline No. & Kode Sampel & $\mathrm{X}$ & $\mathrm{Y}$ & $\mathrm{x}$ & $\mathrm{y}$ & $\mathrm{x}^{2}$ & $\mathrm{y}^{2}$ & $\mathrm{xy}$ \\
\hline 1 & 2 & 3 & 4 & 5 & 6 & 7 & 8 & 9 \\
\hline 1. & 201801 & 8,5 & 7,5 & 0,2 & $-0,5$ & 0,04 & 0,25 & $-0,1$ \\
2. & 201802 & 8,5 & 7 & 0,2 & -1 & 0,04 & 1 & $-0,2$ \\
3. & 201803 & 7,5 & 7 & $-0,8$ & -1 & 0,64 & 1 & 0,8 \\
4. & 201804 & 8 & 8,5 & $-0,3$ & 0,5 & 0,09 & 0,25 & $-0,15$ \\
5. & 201805 & 8,5 & 9,5 & 0,2 & 1,5 & 0,04 & 2,25 & 0,3 \\
6. & 201806 & 8 & 7 & $-0,3$ & -1 & 0,09 & 1 & 0,3 \\
7. & 201807 & 9 & 8,5 & 0,7 & 0,5 & 0,49 & 0,25 & 0,35 \\
8. & 201808 & 9 & 8 & 0,7 & 0 & 0,49 & 0 & 0 \\
9. & 201809 & 9,5 & 9,5 & 1,2 & 1,5 & 1,44 & 2,25 & 1,8 \\
10. & 201810 & 6 & 7,5 & $-2,3$ & $-0,5$ & 5,29 & 0,25 & 1,15 \\
11. & 201811 & 8,5 & 8,0 & 0,2 & 0 & 0,04 & 0 & 0 \\
12. & 201812 & 8,0 & 7,0 & $-0,3$ & -1 & 0,09 & 1 & 0,3 \\
13. & 201813 & 9 & 7,5 & 0,7 & $-0,5$ & 0,49 & 0,25 & $-0,35$ \\
14. & 201814 & 9,5 & 8 & 1,2 & 0 & 1,44 & 0 & 0 \\
15. & 201815 & 7,5 & 7,0 & $-0,8$ & -1 & 0,64 & 1 & 0,8 \\
16. & 201816 & 7,0 & 7,5 & $-1,3$ & $-0,5$ & 1,69 & 0,25 & 1,15 \\
17. & 201817 & 8,5 & 8,0 & 0,2 & 0 & 0,04 & 0 & 0
\end{tabular}

Untuk mengetahui validitasnya dari tabel di atas, kita akan memakai rumus korelasi product moment dengan simpangan yaitu :

$$
r_{\text {hitung }} \frac{n \cdot \sum X Y-\left(\sum X\right)\left(\sum Y\right)}{\sqrt{\left\{n \cdot \sum X^{2}-\left(\sum X\right)^{2}\right)\left\{n \cdot \sum Y^{2}-\left(\sum Y\right)^{2}\right\}}}
$$

Diketahui :

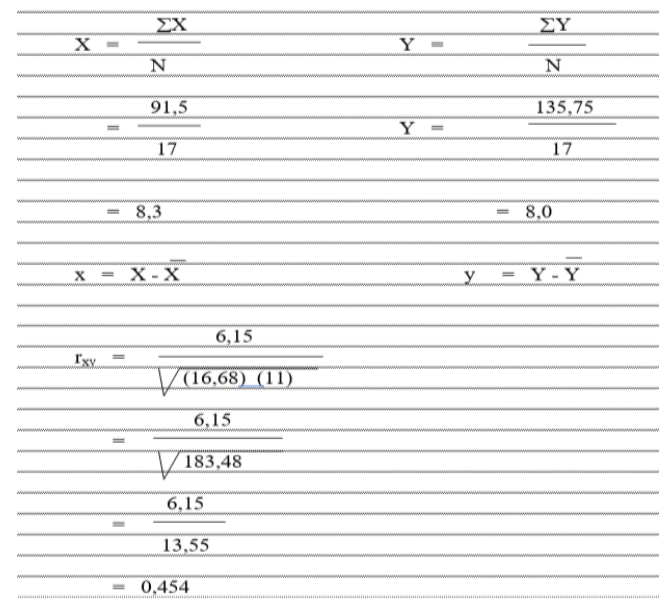


Koefisien korelasi selalu terdapat antara $-1,00$ sampai +1,00. Namun karena dalam menghitung sering dilakukan pembulatan angka-angka sangat mungkin diperoleh koefisien lebih dari 1,00. Koefisien negatif menunjukkan hubungan kebalikan sedangkan koefisien positif menunjukkan adanya kesejajaran. Untuk mengadakan interpretasi mengenai besarnya koefisien dapat ditentukan sebagai berikut :

$$
\begin{array}{ll}
* \text { Antara } 0,80-1,00 & =\text { sangat tinggi } \\
* \text { Antara } 0,60-0,80 & =\text { tinggi } \\
* \text { Antara } 0,40-0,60 & =\text { cukup } \\
* \text { Antara } 0,20-0,40 & =\text { rendah } \\
* \text { Antara } 0,00-0,20 & =\text { sangat rendah }
\end{array}
$$
Untuk membandingkan tingkat validitas dengan kelas VIII B kita lihat tabel berikut :

Tabel 5. Persiapan Mencari Validitas Tes Prestasi IPS Ekonomi untuk Kelas VII B dengan Rumus Koefisien Korelasi Product Moment dengan Simpangan Siswa kelas VIII SMP Negeri 3 Ulaweng Kecamatan Ulaweng Kabupaten Bone

\begin{tabular}{ccccccccc}
\hline No. & Kode Sampel & $\mathrm{X}$ & $\mathrm{Y}$ & $\mathrm{x}$ & $\mathrm{Y}$ & $\mathrm{x}^{2}$ & $\mathrm{y}^{2}$ & $\mathrm{xy}$ \\
\hline 1 & 2 & 3 & 4 & 5 & 6 & 7 & 8 & 9 \\
\hline 1. & 201801 & 7,5 & 7 & 0,1 & 0,5 & 0,01 & 0,25 & 0,05 \\
2. & 201802 & 6 & 5 & $-1,4$ & $-1,5$ & 1,96 & 2,25 & 2,1 \\
3. & 201803 & 9,5 & 9 & 2,1 & 2,5 & 4,41 & 6,25 & 5,5 \\
4. & 201804 & 7 & 5,5 & $-0,4$ & -1 & 0,16 & 1 & 0,4 \\
5. & 201805 & 7,5 & 5 & 0,1 & $-1,5$ & 0,01 & 2,25 & $-0,15$ \\
6. & 201806 & 9,5 & 9 & 2,1 & 2,5 & 4,41 & 6,25 & 5,25 \\
7. & 201807 & 7,5 & 7 & 0,1 & 0,5 & 0,01 & 0,25 & 0,05 \\
8. & 201808 & 5,5 & 5 & $-1,9$ & $-1,5$ & 3,61 & 2,25 & 2,85 \\
9. & 201809 & 6,5 & 6,5 & $-0,9$ & 0 & 0,81 & 0 & 0 \\
10. & 201810 & 7,5 & 6 & 0,1 & $-0,5$ & 0,01 & 0,25 & $-0,05$ \\
11. & 201811 & 7,5 & 6,5 & 0,1 & 0 & 0,01 & 0 & 0 \\
12. & 201812 & 7,5 & 7,5 & 0,1 & 1 & 0,01 & 1 & 0,1 \\
13. & 201813 & 6,5 & 5,5 & $-0,9$ & -1 & 0,81 & 1 & 0,9
\end{tabular}

Jurnal Pendidikan Mandala

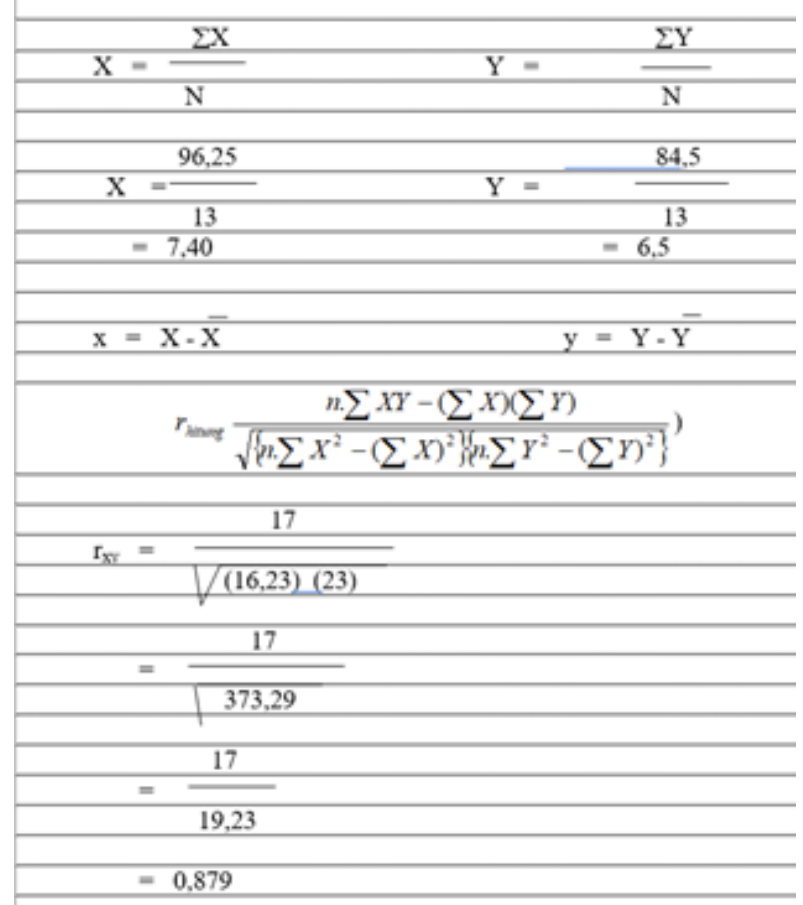

Koefisien korelasi selalu terdapat antara $-1,00$ sampai +1,00. Namun karena dalam menghitung sering dilakukan pembulatan angka-angka sangat mungkin diperoleh koefisien lebih dari 1,00. Koefisien negatif menunjukkan hubungan kebalikan sedangkan koefisien positif menunjukkan adanya kesejajaran. Untuk mengadakan interpretasi mengenai besarnya koefisien dapat ditentukan sebagai berikut :

* Antara 0,80-1,00 = sangat tinggi

* Antara 0,60-0,80 = tinggi

* Antara 0,40 -0,60 = cukup

* Antara 0,20 - 0,40 = rendah

* Antara 0,00-0,20 = sangat rendah

Untuk membandingkan tingkat validitas dengan kelas VIII B kita lihat tabel berikut :

Tabel 6. Persiapan Mencari Validitas Tes Prestasi IPS Ekonomi untuk Kelas VII B dengan Rumus Koefisien Korelasi Product Moment dengan Simpangan Siswa kelas VIII SMP Negeri 3 Ulaweng Kecamatan Ulaweng Kabupaten Bone 


\begin{tabular}{ccccccccc}
\hline No. & Kode Sampel & $\mathrm{X}$ & $\mathrm{Y}$ & $\mathrm{x}$ & $\mathrm{Y}$ & $\mathrm{x}^{2}$ & $\mathrm{y}^{2}$ & $\mathrm{xy}$ \\
\hline 1 & 2 & 3 & 4 & 5 & 6 & 7 & 8 & 9 \\
\hline 1. & 201801 & 7,5 & 7 & 0,1 & 0,5 & 0,01 & 0,25 & 0,05 \\
2. & 201802 & 6 & 5 & $-1,4$ & $-1,5$ & 1,96 & 2,25 & 2,1 \\
3. & 201803 & 9,5 & 9 & 2,1 & 2,5 & 4,41 & 6,25 & 5,5 \\
4. & 201804 & 7 & 5,5 & $-0,4$ & -1 & 0,16 & 1 & 0,4 \\
5. & 201805 & 7,5 & 5 & 0,1 & $-1,5$ & 0,01 & 2,25 & $-0,15$ \\
6. & 201806 & 9,5 & 9 & 2,1 & 2,5 & 4,41 & 6,25 & 5,25 \\
7. & 201807 & 7,5 & 7 & 0,1 & 0,5 & 0,01 & 0,25 & 0,05 \\
8. & 201808 & 5,5 & 5 & $-1,9$ & $-1,5$ & 3,61 & 2,25 & 2,85 \\
9. & 201809 & 6,5 & 6,5 & $-0,9$ & 0 & 0,81 & 0 & 0 \\
10. & 201810 & 7,5 & 6 & 0,1 & $-0,5$ & 0,01 & 0,25 & $-0,05$ \\
11. & 201811 & 7,5 & 6,5 & 0,1 & 0 & 0,01 & 0 & 0 \\
12. & 201812 & 7,5 & 7,5 & 0,1 & 1 & 0,01 & 1 & 0,1 \\
13. & 201813 & 6,5 & 5,5 & $-0,9$ & -1 & 0,81 & 1 & 0,9
\end{tabular}

Diketahui :

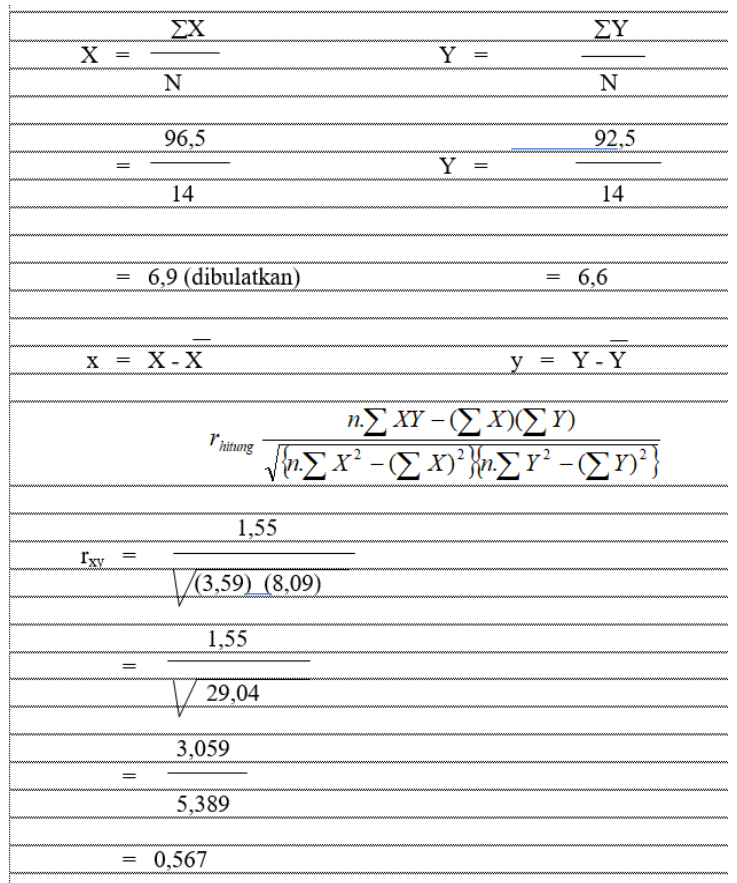

Besarnya koefisien korelasi adalah berada antara 0,800 - 1,00, sehingga dengan demikian angka tersebut dikategorikan sangat tinggi.

Selanjutnya kita akan melihat tabel persiapan untuk mencari validitas tes ekonomi untuk kelas VIII C.

Tabel 7. Persiapan mencari Validitas Tes Prestasi IPS Ekonomi untuk Kelas VII C dengan Rumus Koefisien Korelasi Product Moment dengan Simpangan Siswa kelas VIII SMP Negeri 3 Ulaweng Kecamatan Ulaweng Kabupaten Bone

\begin{tabular}{ccccccccc}
\hline No. & Kode Sampel & $\mathrm{X}$ & $\mathrm{Y}$ & $\mathrm{x}$ & $\mathrm{Y}$ & $\mathrm{x}^{2}$ & $\mathrm{y}^{2}$ & $\mathrm{Xy}$ \\
\hline 1 & 2 & 3 & 4 & 5 & 6 & 7 & 8 & 9 \\
\hline 1. & 201801 & 6 & 5,5 & $-0,9$ & $-1,1$ & 0,81 & 1,21 & 0,00 \\
2. & 201802 & 7,5 & 7 & 0,6 & 0,4 & 0,36 & 0,016 & 0,24 \\
3. & 201803 & 7 & 6,5 & 0,1 & $-0,1$ & 0,01 & 0,01 & $-0,01$ \\
4. & 201804 & 6,5 & 6 & $-0,4$ & $-0,6$ & 0,16 & 0,36 & $-0,096$ \\
5. & 201805 & 7 & 6,5 & 0,1 & $-0,1$ & 0,01 & 0,01 & $-0,06$ \\
6. & 201806 & 6,5 & 7 & $-0,4$ & 0,4 & 0,16 & 0,16 & 0,064 \\
7. & 201807 & 7 & 7,5 & 0,1 & 0,9 & 0,01 & 0,081 & 0,09 \\
8. & 201808 & 7,5 & 6,5 & 0,6 & $-0,1$ & 0,36 & 0,01 & $-0,06$ \\
9. & 201809 & 7,5 & 7 & 0,6 & 0,4 & 0,36 & 0,16 & 0,24 \\
10. & 201810 & 7 & 6,5 & 0,1 & $-0,1$ & 0,01 & 0,01 & $-0,01$ \\
11. & 201811 & 7,5 & 6,0 & 0,6 & $-0,6$ & 0,36 & 0,36 & $-0,36$ \\
12. & 201812 & 6,0 & 8,5 & $-0,9$ & 1,6 & 0,81 & 2,56 & 1,44 \\
13. & 201813 & 6,5 & 5,5 & $-0,4$ & $-1,1$ & 0,16 & 1,21 & 0,44 \\
14. & 201814 & 7,0 & 6,5 & 0,1 & $-0,1$ & 0,01 & 0,01 & $-0,01$ \\
\hline & Jumlah & 96,5 & 92,5 & & & 3,59 & 8,09 & 3,059 \\
\hline
\end{tabular}

Diketahui :

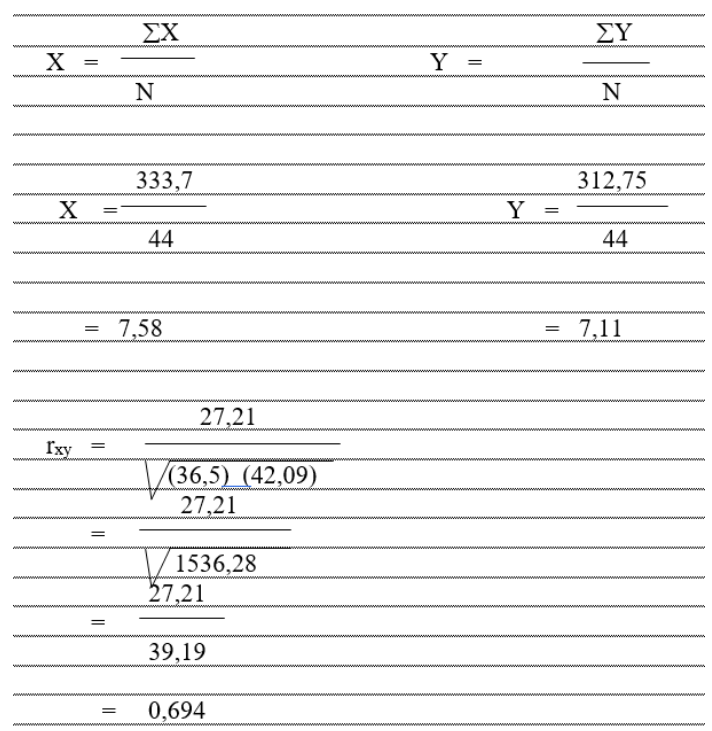

Besarnya validitas koefisien korelasinya adalah berada setara $0,400-0,600$, sehingga dengan demikian angka tersebut dikategorikan cukup.

Apabila jumlah secara keseluruhan hasil validitas koefisien korelasi antara kelas VIII A, VIII B dan VIII C, maka akan didapat jumlah keseluruhannya yaitu :

Rumus :

$$
r_{\text {hitung }} \frac{n \cdot \sum X Y-\left(\sum X\right)\left(\sum Y\right)}{\sqrt{\left.\left\{n \cdot \sum X^{2}-\left(\sum X\right)^{2}\right), n \cdot \sum Y^{2}-\left(\sum Y\right)^{2}\right\}}}
$$

$\mathrm{D}$

Diketahui :

Jumlah keseluruhan $X=333,7$

Jumlah keseluruhan $\mathrm{Y}=312,75$

Jumlah keseluruhan $\mathrm{x}^{2}=36,5$

Jumlah keseluruhan $\mathrm{y}^{2}=42,09$ 
Jumlah keseluruhan xy $=27,21$

Diketahui :

Kita ketahui bahwa hasil dari jumlah keseluruhan validitas antara kelas VIII A, VIII $\mathrm{B}$ dan VIII $\mathrm{C}$ dengan menggunakan rumus diperoleh angka atau hasil akhir sebesar 0,694. Dengan demikian sesuai dengan interpretasi mengenai besarnya koefisien korelasi adalah antara 0,600 - 0,800 dikategorikan nilai tinggi. Untuk lebih jelasnya dapat dilihat pada tabel di bawah ini yang memuat tentang analisis sosial menurut pokok uji.

Tabel 8. Analisis Soal menurut Pokok Uji Siswa kelas VIII SMP Negeri 3 Ulaweng Kecamatan Ulaweng Kabupaten Bone.

\begin{tabular}{|c|c|c|c|}
\hline No. & Pokok Uji & $\begin{array}{c}\text { Salah } \\
\text { Frekuensi }\end{array}$ & $\begin{array}{c}\text { Persentase } \\
(\%)\end{array}$ \\
\hline 1. & $\begin{array}{ll}\text { Menentukan } & \text { tingkat } \\
\text { analisis siswa dalam }\end{array}$ & 22 & 50,00 \\
\hline 2. & $\begin{array}{l}\text { menerima materi } \\
\text { ekonomi. }\end{array}$ & 10 & 22,73 \\
\hline 3. & $\begin{array}{l}\text { Menentukan tingkat } \\
\text { analisis siswa dalam } \\
\text { berdiskusi kelompok. } \\
\text { Mengerjakan soal-soal } \\
\text { dengan teknik objektif. }\end{array}$ & 12 & 27,27 \\
\hline & Jumlah & 44 & 100,00 \\
\hline
\end{tabular}

Berdasarkan hasil pengolahan di atas, dapat dijadikan bahan masukan bagi guru-guru ekonomi terutama yang mengajar di kelas kelas VIII SMP Negeri 3 Ulaweng Kecamatan Ulaweng Kabupaten Bone. dan berdasarkan dengan kurikulum pengajaran sekarang setiap guru dituntut untuk memperbanyak memberikan kegiatan proses pembelajaran dengan sistem dydisity kepada siswa agar kesulitan dan keterlambatan materi yang dialami selam aini dapat teratasi.

\section{Pembahasan}

Berdasarkan deskripsi data, maka jawaban untuk setiap nomor tes adalah 12 nomor dari 25 nomor soal dengan jumlah siswa yang menjawab salah lebih dari 10 soal, ini terlihat kesalahan siswa berada pada level 10 14 kesalahan dalam menjawab soal-soal yang diujikan. Kenyataan tersebut memberikan bukti bahwa seperdua dari 44 siswa sampel belum mampu menganalisis dengan baik.

Perlu diketahui bahwa analisis siswa pada standar nilai variabel yang telah ditetapkan dalam penelitian ini yaitu 80 persen ke atas adalah nilai tinggi, sedangkan siswa sampel yang mencapai kriteria yaitu 75 persen ke atas, maka dapat dikatakan bahwa analisis transaksional siswa dalam proses pembelajaran dalam mata pelajaran Ekonomi siswa kelas VIII SMP Negeri 3 Ulaweng Kecamatan Ulaweng Kabupaten Bone.dapat dikatakan belum terlalu memuaskan sesuai dengan apa yang diharapkan.

Namun, perlu diketahui dari pernyataan di atas, bahwa dengan melihat hasil akhir belajar, siswa secara keseluruhan berdasarkan analisis validitas, proporsi, mapun persentase serta distribusi frekuensi, maka secara umum belum dikatakan berhasil atau memenuhi target. Berdasarkan nilai tes ekonomi untuk 44 orang yang diambil sampel secara acak dari 3 kelas yaitu kelas VIII A, VIII B dan VIII C pada distribusi frekuensi dapat dilihat bahwa hanya 22 siswa yang memperoleh nilai kategori tinggi yaitu nilai 75 - 93 atau 50 persen sedangkan sisanya 22 orang siswa yang memperoleh nilai dalam kategori rendah yaitu nilai 50 - 71 atau 50 persen. Melihat kenyataan tersebut dan berdasarkan kriteria 75 persen ke atas dapat dikategorikan proses pembelajaran berhasil. Dengan demikian secara umum tingkat menganalisis siswa menjawab soal-soal yang disajikan belum berhasil dengan baik. Berdasarkan proporsi dapat dikatakan bahwa frekuensi benar jumlah soal yang diberikan oleh siswa terhadap analisis soal menurut pokok uji, khusus isi soal sudah dapat dikategorikan baik, ini terbukti dari 44 siswa sampel umumnya mempunyai frekuensi benar sebesar 85 persen dan frekuensi salah sebesar 15 persen (dapat dilihat pada tabel analisis soal menurut pokok uji). Berdasarkan persentase analisis soal keseluruhan, maka dapat dikatakan bahwa frekuensi siswa yang menjawab jumlah soal 
yang benar sebanyak 85 persen, sedangkan frekuensi siswa yang menjawab soal salah sebanyak 15 persen, sehingga secara umum tingkat analisis siswa dalam proses pembelajaran adalah baik. Berdasarkan hasil penelitian menunjukkan bahwa $\mathrm{r}$ hitung = 0,694, pada taraf signifikan 5 persen $=0,297$ dan 1 persen $=0,384$ dimana $N=44$. Untuk membuktikan hipotesis apabila nilai $\mathrm{r}$ hitung lebih besar daripada nilai taraf signifikan 5 persen dan 1 persen, maka hipotesis nihil $\left(\mathrm{H}_{0}\right)$ ditolak dan hipotesis alternatif $\left(\mathrm{H}_{1}\right)$ diterima.

\section{SIMPULAN}

Berdasarkan hasil pengolahan data dan pengujian serta pembuktian hipotesis penelitian.Hubungan analisis transaksional adalah merupakan suatu cara untuk menganalisis bagaimana hubungan dengan analisis transaksional dalam proses pembelajaran. Adanya hubungan yang signifikan dimana $r$ hitung lebih besar daripada $\mathrm{r}$ tabel product moment yaitu $\mathrm{r}$ hitung $=0,694$ untuk $\mathrm{r}$ tabel 5 persen $=0,297$ dan 1 persen $=$ 0,384 dimana $\mathrm{N}=44$, maka Hipotesis alternatif (H1). Diterima. Secara umum dapat dikatakan bahwa masih ada perbedaan cara menerima materi atau pelajaran ekonomi antara kelas yang satu dengan yang lainnya. Kenyataan ini dapat dilihat pada tabel analisis distribusi frekuensi, analisis validitas dan proporsi.

Saran

Untuk lebih meningkatkan analisis siswa hendaknya pengajaran menganalisis dioptimalkan dan diberikan alokasi waktu yang sama dengan proses pembelajaran yang semestinya. Agar analisis transaksional dalam proses pembelajaran dapat berjalan lancar sebaiknya memperhatikan ketetapan pengajaran dalam mengukur dan mengklasifikasi perkembangan analisis siswa.

\section{Keterbatasan Penelitian}

Keterbatasan Penelitian ini masih jauh dari sempurna, mengingat masih terdapat ketentuan seperi model pembelajaran ini terkadang sulit dalam Jurnal Pendidikan Mandala merencanakannya karena terbentur dengan keadaan siswa dalam kegiatan belajar dan obserbasi serta kriteria keberhasilan belajar siswa ditentukan oleh kemampuan siswa menguasai materi pelajaran.

\section{DAFTAR PUSTAKA}

Amier Daien Indra Kusuma. 2001. Evaluasi Pendidikan. Lembaga Penerbitan IKIP Malang. Terbitan Ke-II.

Arikunto, Suharsimi. 2004. Prosedur Penelitian Evaluasi Pendidikan. Jakarta.

2005. Dasar-dasar Evaluasi Pendidikan. Jakarta : Bumi Aksara.

Buchari Alma, 2010. Untuk penelitian Statistik pendidikan,sosial, Ekonomi Komunikasi dan Bisnis, Matematika. Jakarta. Alfabeta. Bandung.

Campos L, Cormick P.M.Sc. 2002. Analisis Transaksional, Aturan Permainan bagi Komunikasi yang Baik Antar Pribadi. Yayasan Cipta Loka Caraka. Jakarta.

Depdikbud. 2002. Materi Dasar Pendidikan Program Akta Mengajar $V$. Buku Metodologi Penelitian. Depdikbud. Jakarta.

Gazali M.A, R. Prof. 2003. Sekolah dan Masyarakat. Ganaco NV. Bandung.

Hadi, Sutrisno. 2003. Metode Research. Yogyakarta. Gajah Mada Unversity Press.

Iskandar Wiryokusumo M.Sc \& J. Mandalika, ed., 2003. Kumpulan Pikiran-pikiran dalam Pendidikan. Surabaya.

Nurkancana, 2009. Analisis transaksional penerbit. Bulan Bintang. Jakarta. 
Ngadiyono AY, Sartji Ganama, Sudira. 2001. Beberapa Catatan tentang Teori Relasi. Penataran Lokakarya Gelombang 2 dan 3. Proyek Pengembangan Pendidikan Guru (P3G), Departemen P dan K. Jakarta.

P.T.P.R. 2003. Pengetahuan Dasar Penelitian dan Statistik. Airlangga University Press. Jatim.

Sudjana. 2002. Statistika. Jilid II. Tarsito : Bandung.

Sutrisno Hadi. 2003. Statistik. Fakultas Psychology UGM. Yogyakarta.

Tim Bimbingan dan Penyuluhan.2000. Pengantar Bimbingan dan Penyuluhan. Tim Penerbit IKIP Surabaya.

Tim Pembinaan dan Bahan-bahan Penataran Pegawai RI, Undang-Undang Dasar, Pedoman Penghayatan dan Pengamalan Pancasila, Garis-Garis Besar Haluan Negara, Tim Pembinaan dan Bahan-bahan Penataran Pegawai RI. Jakarta.

UNA Kartawisastra H. 2003. Analisis Transaksional Penataran. Lokakarya Gelombang 2 dan 3. Proyek Pengembangan Pendidikan Guru (P3G) Departemen P dan K. Jakarta.

UNA Kartawisastra H., Maman Acydiat,

\section{Soeranto M.B., 2003. Masalah Aktualisasi Diri. Penataran Lokakarya Gelombang 2 dan 3. Proyek Pengembangan Pendidikan Guru (P3G) Departemen P dan K. Jakarta.}

Pribadi. Penataran Lokakarya Gelombang 2 dan 3 Proyek Pengembangan Pendidikan Guru (P3G) Departemen P dan K. Jakarta.

Zakiyah Darodjat Dr., 2002. Ilmu Jiwa Agama. Penerbit Bulan Bintang : Jakarta.

Woroharini, Ida Komang Adita. 2003. Keterampilan Berkomunikasi Antar 